Наталья Пушкарева, Наталья Мицюк

\title{
У ИСТОКОВ МЕДИКАЛИЗАЦИИ: ОСНОВЫ РОССИЙСКОЙ СОЦИАЛЬНОЙ ПОЛИТИКИ В СФЕРЕ РЕПРОДУКТИВНОГО ЗДОРОВЬЯ (1760-1860ГГ.)
}

\begin{abstract}
Статья посвящена изучению процесса перехода от народного к научному акушерству в России периода позднего Нового времени. Наша цель проанализировать особенности процесса медикализации деторождения и патологизации родового акта во врачебном дискурсе. Источниками исследования выступила литература по акушерству с 1760-х гг. до середины XIX в. Актуальными явились подходы социальной истории медицины, гендерной истории и феминисткой антропологии, а также методы контент-анализа и дискурсивного анализа. Необходимость в научном осмыслении процесса деторождения в России возникла во второй половине XVIII в., что было связано как с развитием научной медицины в целом, так и с открытием первых учебных заведений по обучению повивальному искусству. На пути распространения научного акушерства стояли гендерные стереотипы общества в отношении недопустимости мужчин к осмотру и изучению женского тела. Врачиакушеры, стремясь обосновать собственный авторитет среди медицинских специальностей и превосходство над носительницами традиционных знаний, писали об особой политической значимости своего дела. Авторитет научного акушерства утверждался за счет развития учения об оперативном акушерстве. Акушерские операции, применение новых технологических инструментов, гинекологические операции становились преимуществами клиницистов. Утверждение социального контроля врачей над сферой деторождения происходило через патологизацию родов. Клиническое пространство превращалось в область экспериментов над женским телом, которое стало рассматриваться в качестве объекта
\end{abstract}

Наталья Львовна Пушкарева - д.и.н., профессор, Институт этнологии и антропологии PАН им. Н.Н. Миклухо-Маклая, Москва, Россия. Электронная почта: pushkarev@mail.ru

Наталья Александровна Мицюк - д.и.н., доцент, Смоленский государственный медицинский университет, Смоленск, Россия. Электронная почта: mitsyuk.natalia@gmail.com 
наблюдений, и особых практик со стороны медиков. Роженица из активного участника, субъекта родовой деятельности становилась пассивным объектом врачебных манипуляций. Процесс медикализации женского репродуктивного здоровья выражался и в том, что акушерская наука, включив в себя учение о половом развитии женского организма, взяла под контроль целый жизненный период женщины - от созревания до беременности, родов, послеродового восстановления и женских болезней. К середине XIX в. утвердилась иерархия в деятельности врача-акушера и повитухи. Врачи-акушеры стали контролировать область патологического акушерства, оказывая пособие при «трудных родах». Сформировалась усредненная модель «правильных» и «неправильных родов», любые отклонения от «нормы» стали рассматриваться как повод для врачебного вмешательства.

Ключевые слова: история родов, история акушерства, медикализация, повитухи

DOI: $10.17323 / 727-0634-2017-15-4-515-530$

Современная социальная политика в сфере репродуктивного здоровья направлена на модернизацию медицинских учреждений, повышение качества медицинских услуг, большее вовлечение женщин в сферу профилактического контроля над собственным репродуктивным здоровьем (Холостова 2013:314-315). Домашние роды, избегание регулярных гинекологических осмотров и консультативных приемов во время беременности, отказ от врачебных рекомендаций - все это официальная медицина рассматривает в качестве отрицательных девиаций. Область родовспоможения представляется медикализированной и контролируемой со стороны экспертного сообщества, вписанного в этакратический гендерный порядок (Здравомыслова, Темкина 2015: 332-349). Когда начался данный процесс в истории России? Каким образом проходил переход от «естественных», домашних родов к клиническим? Какую роль в данном процессе сыграло медицинское сообщество? В какой степени женское репродуктивное здоровье через вовлечение в область социальной политики оказалось в зоне мужского врачебного контроля? Цель этой статьи состоит в том, чтобы проанализировать процесс медикализации женского репродуктивного здоровья в России на этапе перехода от народного акушерства к научному (1760-1860 гг.). При этом мы стремимся понять, насколько изменения в сфере родовспоможения отражали социальную политику российского государства в условиях отсутствия системы медицинских учреждений, каким образом и с помощью чего утверждался социальный контроль над сферой женского репродуктивного здоровья.

Термин медикализация, столь привычный социологам (Темкина 2014), внесен в историческую науку американскими и западноевропейскими гендерными историками и социальными историками медицины, которые 
стали рассматривать родовспоможение как сферу выраженного социального дисциплинирования, мужского доминирования и женского подчинения (Leavitt 1986; Gelis 1991; Borst 1995; Green 2008; Wilson 2013). Социальные отношения в сфере репродуктивного здоровья - процесс медикализации деторождения - редко интересовали отечественных историков. Авторы (преимущественно историки медицины) концентрируются на изучении истории научного знания и развития стационарного акушерства (Груздев 1910; Данилишина 1998; Яковенко 2008).

Социологи проявление медикализации репродуктивного жизненного цикла видят именно в том, что роды перестают быть автономным опытом женщин, а становятся «сферой медицинской экспертизы» (Здравомыслова, Темкина 2015: 621). В российских исторических исследованиях это понятие, означающее социальный механизм, с помощью которого немедицинские проблемы определяются в терминах болезни или расстройства, почти не используется. В социологических работах истоки медикализации репродукции в России отыскиваются в советском периоде, исторические углубления за его пределами не делаются. Наша задача состоит в анализе механизмов, стратегий и приоритетов процесса перехода от «бабичьего дела» к научному акушерству в условиях Нового времени, что в дальнейшем составляет основу социальной политики в области охраны репродуктивного здоровья. Будучи приверженками гендерной теории, мы считаем важным сфокусировать внимание на согласованности этого процесса с интересами подзащитных - то есть женщин, выступавших в системе научных знаний в роли объекта («пациенток»).

Эмпирическим материалом стала российская акушерская литература с 1760-х гг. (время публикации первой работы по акушерству) и до середины XIX в., когда в стране появились родильные стационары, кафедры акушерства и женских болезней при университетах. В работе с литературой использовался контент-анализ и дискурсивный анализ.

\section{Ранняя акушерская литература XVIII - нач. XIXв. и отношение ее авторов к традициям в повивальном деле}

Вплоть до позднего Нового времени в стране доминировало народное акушерство (Пушкарева 1996). В абсолютном большинстве случаев, как в семье простолюдинов, так и в семьях привилегированных сословий, на роды приглашались повивальные бабки и сельские повитухи, не имевшие специального образования. Деторождение считалось делом естественным, роженица - его активной участницей. Необходимость в научном осмыслении процесса деторождения в России возникла во второй половине XVIII в., что связано как с развитием научной медицины в целом, так и с открытием первых учебных заведений по обучению повивальному искусству. Видимый прогресс научного знания оборачивался изменениями в социальной сфере, 
в гендерном измерении общества. Истоки современной социальной политики в отношении беременных и рожающих женщин могут быть проанализированы на основе первых российских печатных материалов, характеризующих процесс медикализации женского репродуктивного здоровья.

Анализ литературы по акушерству и гинекологии показывает, что за столетие (с 1760 г.) в России было опубликовано 16 учебников с практическими рекомендациями по повивальному делу, принадлежавших отечественным авторам, и около 30 переводных. Первые научные работы по акушерству написаны просто, доступно, часто в форме вопросов-ответов. Они начинались описанием традиционно сложившейся практики в этой области обыденности. Главными участниками родового акта были роженица и повитуха, в связи с этим можно говорить о сохранении женского пространства родов на всем протяжении XVIII в. Состояние беременности - «как младенец бытие свое в матке начинает» (Бодлок 1786:22) - поначалу в литературе не описывалось, умалчивались и описания женской физиологии. Представления врачей о признаках начала вынашивания плода почти не отличались от известных любой повитухе. Врачи разделяли их на «сомнительные»«запор месячных кровей», «позывание на рвоту», рвота, «омерзение от явств», «прихоть к явствам непорядочная», «прибавления брюха», «напряжение титек» - и «верные» - «устье маточное накрепко затворяется», «ежели рыльцо наподобие хобота из устья маточного во влагалище маточное сделается» (Там же:22-23).

О специальных акушерских инструментах, как и операциях речи не было. В первых описаниях повивального дела говорилось лишь о наличии у врача или повитухи свежего коровьего масла, тонких нитей, так же бельевых «по обеим концам узлами завязанных», ножниц, вина, сахара, чистой воды (Там же:30-31). Проверенные временем народные практики находили в XVIII в. точнейшее воспроизведение в текстах печатных рекомендаций. Среди них требование к повитухе «дружески уговаривать» роженицу тужиться, «доверясь» природе (Бодлок 1786:31; Константинович 1802:9). Для облегчения потуг предлагалось использовать «правление живота», «становление клистира», «прикидание банок», «припускание пиявок». Действия самой роженицы, ее поведение, расположение во время потуг не регламентировались, ей позволялось лежать и вдоль, и поперек кровати, находиться в положении сидя (Константинович 1802: 8). При трудных родах использовался «поворот на ножку». Никаких данных об использовании кесарева сечения найти не удалось. После рождения младенца на повитухе лежала обязанность перевязать пуповину и обеспечить полный выход последа.

Необходимость выделения акушерства в качестве самостоятельного направления в медицине и отдельной специализации при подготовке врачей впервые в России обосновывалось в оригинальном сочинении по акушерству Нестора Максимовича Максимовича-Амбодика. Борьба за авторитет врачей в вопросах родовспоможения началась с критики традиционных 
действий повивальных бабок и в целом народного акушерства (Максимович-Амбодик 1786: 7). С работы «Искусство повивания или Наука о бабичном деле» в российской культуре берет начало противостояние научного и народного акушерства, равно как утверждение авторитета врача.

В сочинении Максимовича-Амбодика беременность, послеродовое состояние рассматривались в качестве важных периодов в акушерской практике и науке, требующие особого поведения женщины и отношения врача. Это свидетельствовало в пользу начавшегося процесса медикализации деторождения. Правильный образ жизни беременной, по мнению врача, должен был складываться из частых прогулок на свежем воздухе, диеты в питании, отсутствии душевных волнений, отказе от модных тенденций в женской одежде - каблуков, стесняющих повязок (Максимович-Амбодик 1785: 8-16). В послеродовой период предполагалось использовать особые врачебные манипуляции для лучшего восстановления родильницы, налаживания лактации, предписывались четкие правила по уходу за новорожденным, уделялось внимание диетике родильницы.

В традиционном акушерстве ритуальные действия, связанные с магическими практиками и религиозными верованиями, преследовали цель облегчения страданий роженицы. Рациональный подход Амбодика состоял в отрицании любых, кроме научных, методов родовспоможения. Он критиковал применение кровопускания, употребление во время родов рвотных веществ, спиртных напитков, наложение давящей повязки на живот родильницы, несменяемость родильной рубашки после родов. Врач призывал отказаться от любых манипуляций с ладанками, не посылать в церковь «с просьбами и подарками», отмечая, что эти процедуры «хоть и безобидны по сути, но совершенно бесполезны», отвергал традиционные ритуалы с «детским местом» (Максимович-Амбодик 1784: 12-13).

Авторитет врача, его техническую подкованность стали символизировать акушерские щипцы, которые Амбодик активно использовал в своей практике (Максимович-Амбодик 1784: 42-43). Хирургические инструменты начали проникать в сферу родовспоможения, символизируя одновременно профессионализм врача, его преимущества перед повитухами и предмет страхов для родильниц.

\section{Утверждение медицинской гегемонии в контроле репродуктивного поведения (1800-1840гr.)}

Младшие современники и продолжатели дела Максимовича-Амбодика В. М. Рихтер, Д. И. Левитский, С. В. Хотовицкий, И. Тиханович, К. Верман сделали немало для обоснования технократической модели родов. Авторитет акушерской науки в России утверждался не столько с распространением школ и институтов для повивальных бабок, которые в павловскую и александровскую эпохи удвоили свое число, сколько с открытием специальных 
кафедр акушерства при университетах, где началось преподавание акушерства для будущих врачей. Основное содержание врачебного дискурса состояло в обосновании самостоятельности предмета акушерской науки и расширении сферы деятельности врача-акушера: женские болезни и все связанное с рождением детей стали частью искусства врачевания. В данный период основная риторика авторов акушерской литературы представляла систему аргументов, оправдывавших доминирование в области родовспоможения врачей-профессионалов перед лицом доморощенных повитух. Переход деторождения в важную область социальной политики государства проходил по пути обоснования престижа и профессионализма врачей-акушеров, что в социологии профессий рассматривается в качестве неовеберианской перспективы (Abbott 1988; Романов, Ярская-Смирнова 2013).

Главным же препятствием в утверждении авторитета врача-акушера в России выступили гендерные стереотипы, сформированные православной этикой, немало способствовавшей укреплению представлений о недопущении мужчин к осмотру и изучению женского тела. Врача могли привлечь к суду только за осмотр женщины без достаточных к тому оснований: в 1829 г. получил огласку случай доктора Баженова, осужденного за осмотр роженицы без повивальной бабки (Груздев 1910: 29). Последняя продолжала оставаться основной участницей родового акта, и сфера ее деятельности на практике оказывалась куда шире, чем у врачей.

Стараясь обосновать превосходство своих знаний над опытом неграмотных повитух, акушеры писали об особой политической значимости своего дела, составляющего «важный предмет мудрой государственной политики» (цит по: Цвелев 2006: 85). Умение производить осмотр, подтверждая беременность или женское заболевание (опухоль), превратилось в стигмат профессиональной компетентности. Блуждавшая в потемках российская диагностика того времени наряду с медицинскими фактами («остановление или изменения месячных очищений», «постепенное напухание живота и перемена пупка», «возвышение матки», «перемена шейки и отверстия», «перемена грудей») упоминала самые невероятные подтверждения успешного зачатия: «особое чувство удовольствия при совокуплении», «озноб, летучий жар, от живота по всему телу простирающийся», боль в животе, «кружение головы, обмороки, усталость» и даже «побуждение складывать ноги» (Левитский 1821:47). Несмотря на развитие представлений о признаках беременности при одновременном сохранении запретов на гинекологический осмотр (Левитский 1821:49; Верман 1832: 78-80), в России начала XIX в. существовал перечень возможных манипуляций «акушерского освидетельствования»: внешнее ощупывание, «рукоосязание» нижней части тела женщины (Верман 1832: 78-80). «Рукоосязания», применяемые повитухами («указательным или средним пальцем, маслом намазанным»), разрешались прежде всего в судебных случаях, когда нужно было подтвердить или опровергнуть «девство» (случаи о беременности при изнасилованиях), 
либо установить способность женщины к исполнению супружеских обязанностей. При проведении этого «акушерского исследования» поза женщины не регламентировалась: «рукоосязание» проводили в стоячем, сидячем, полусидячем, спинном, боковом положении, на родильном стуле, на углу обыкновенного стула, на коленях или локтях (Левитский 1821:93). В живописании подробностей, объяснимых отсутствием или запретом практики на живых людях, можно увидеть процесс превращения медицины в социальный инструмент. Малоописанная ранее на русском языке физиология брака превращалась в оправдание моральной и социальной полезности врачебного ремесла и необходимости тщательного контроля здоровья тех, кто вынашивает детей.

Веря в социальную миссию медицинской науки, врачи предостерегали женщин от стремления получать радости во время беременности и пугали их опасностями для них и будущих детей в случае нарушений запретов. В разделах, посвященных периоду вынашивания, Д.И. Левитский обосновал запрет на «любовные наслаждения» во время беременности, стал ограничивать женское питание, писал о необходимости подготовки организма к лактации: «выправлять сосцы различными способами < .. > например, грудным насосом, стеклянною банкою, посредством наложенных на них гумми-эластических колечек или частичного притягивания перстами» (Там же: 102).

Проникновение мужчин в сферу акушерства вело к рационализации процесса помощи роженицам. Российские акушеры первой половины XIX в., в отличие от своих немецких и французских коллег, предоставили родильницам куда больше свободы в принятии решения, как разрешаться от бремени. В текстах описано множество родильных поз (стоячее, сидячее, коленопреклонное, «пониклое» на коленях и локтях), хотя лежачему положению на спине уже отдавалось предпочтение, пусть он еще и не закрепился в качестве единственно возможного (Там же: 110-115). В многонациональной империи врачи подчас владели отрывочными знаниями, основанными на этнографическом материале о практиках родов в различных местностях России на кровати, в домашнем кресле, с XIX в. на «повивальном стуле» (Левитский 1821:120-121; Верман 1832:93-94).

Акушерская литература начала этого времени убеждает, что повитухи доминировали при домашних родах и их нормальном течении, а врачи утверждали свой авторитет в клиническом пространстве: туда размещали рожениц с патологиями (Горн 1834:V). На протяжении XIX в. в России открылось около двух десятков повивальных институтов, в которых мужчины обучали женщин и присваивали им профессиональные звания. Выпускницы этих школ получали звание ученых повивальных бабок, которые становились основными проводниками профессионального акушерства в российской провинции и противостояли традиционным практикам в родовспоможении. Институты с родильными отделениями и клиниками на протяжении столетия превратились в экспериментальное поле для 
врачебных манипуляций. Сугубо женское дело и опыт были ниспровергнуты со своего пьедестала; по мере того, как врачи расширяли область оперативного акушерства, рожавшие теряли контроль над своими телами, превращаясь в объекты акушерской поддержки и спасения.

Акушерская наука стала развиваться по пути оказания «хирургических пособий» роженице. В трудах профессора Императорской Военно-медицинской академии Н. Дьяконова были перечислены основные хирургические операции, которыми должны были владеть дипломированные акушеры: «употребление щипцов», «разсечение головки младенца», «разсечение младенца», «хрящеразсечение костей лобковых», «разсечение матки», «кесарская операция». Последняя проводилась одним из трех видов разрезов («на боку», «по белой линии», «поперечный»); страдалицы выживали редко. Вопрос, кого именно спасать - мать или ребенка - перед российскими врачами ставился редко; зашивать рассеченную матку врачи не умели, смерть наступала от сепсиса и кровопотери. Хирургическая оснастка акушеров была примитивной: два ножа, зонд с бороздкой, пинцет, иглы кривые и прямые, примочки, шелковые нитки, компрессы, клейкий пластырь (Левитский 1821: 174). Повивальные бабки относились к освоению манипуляций ими не без оправданных предубеждений.

Другой приоритетной областью для врачей стало учение о гинекологии, которое было сосредоточено на изучении разного рода патологий в развитии женской репродукции. В переводных трудах Ж. Капюрона, В. М. Мондата, К. Вестфаля, К.Г. Каруса, А.И. Грубера обосновывалось требование проявлять внимание и наблюдать женский организм с самого детства, чтобы быть в силах помочь и в «плодотворной зрелости» и при «прекращении плодотворного отправления» (Карус 1836:9). Помимо рациональных и практически обоснованных описаний физиологических особенностей женских детородных органов и заболеваний матки, яичников, груди, в этих книгах присутствовали размышления об обнаружении «девичьей немочи», «маточного бешенства» (аналог нимфомании, гиперсексуальности), «истерики» (Там же: VII-X). Предмет акушерской науки из «пособия при родах» разросся и вышел за рамки повивального искусства.

Несомненно, это большой прорыв в развитии гинекологического учения в России, но в области социальной и повседневной истории наблюдался процесс патологизации женского репродуктивного здоровья, которое в отличие от мужского репродуктивного здоровья, попадало под особый экспертный контроль. Многие состояния женского организма, особенно в части полового развития, стали трактоваться как «ненормальные». К примеру, появлялись такие диагнозы как «девичья немочь», менструация стала рассматриваться в качестве проявления болезненного состояния. В работе К.Ф. Дейча она описывалась как болезненное состояние, которому сопутствуют «несносность нрава», расстройство пищеварения, сопровождаемое «гнилостным запахом изо рта», проблемами с голосом, вплоть до кашля, 
чахоточным видом, головной болью, тошнотой, жаром, головокружениями и обмороками (Дейч 1841: 12, 13, 19). Врачи призывали читательниц оставаться дома на протяжении всего периода регул, исключать верховую езду, посещение балов и публичных мест, отказываться от горячих напитков, беречь себя от душевных потрясений и сидения на мягких подушках, особенно «скрестив ноги» (Дейч 1841:26-31). Вводя понятие «половая истерия», врачи стали определять границу того, когда сексуальное поведение женщины нормальное, а когда чрезмерное. Невозможность супружеской пары завести ребенка, бесплодие рассматривались исключительно в качестве женского заболевания. Гинекологический осмотр при помощи специальных инструментов становился важным выражением врачебной квалификации. Подобные примеры подтверждают, что российская медицина начала XIX в.- как и вся европейская - стала, по словам Мишеля Фуко, медициной «патологических реакций» и их проявлений (Фуко 2010: 57).

\section{Патологизация деторождения. Оперативное акушерство в условиях клиники}

С 1840-х гг. в России вышло в свет немало книг и оригинальных исследований по акушерству Г.И. Кораблева, А.Н. Никитина, А.П. Матвеева и И.П. Лазаревича, предназначенных не для обучения российскими врачами полуграмотных повивальных бабок, а для самих медиков. Выход книг с огромным числом медицинских терминов и цитированиями на иностранных языках символизировал разделение обязанностей женщин и мужчин, повивальных бабок и врачей-акушеров, равно как областей применения их знаний и навыков. К женщинам, желавшим быть признанными во врачебном мире как повивальницы, стали предъявлять больше требований, в том числе «телесного», «душевного» и нравственного характера (Кораблев 1843: 10-11). Скажем, Г.И. Кораблев сообщил, что повивальниц необходимо постоянно экзаменовать, проверяя их владение «родовспомогательным искусством», а врачам - наблюдать за беременной, ставить диагнозы в случае отклонения от нормы, владеть комплексом механических средств для принятия родов, знать диетические правила для здоровья роженицы, уметь прописывать соответствующие лекарства (Там же: 7-8). Знания в области «диетики» считались принципиально важными, поскольку именно они, по мнению врачей, помогали предотвратить многочисленные заболевания женщины, ее ребенка, исключали затруднения при родах (Никитин 1847; Матвеев 1856).

Успешность врача в подтверждении или опровержении факта беременности могла резко и скоро повысить его авторитет, стоимость его услуг и безоговорочное приятие предложений о частоте посещений и осмотров. К верным признакам беременности стали относить «маточный шум» и «шум детского места» (Матвеев 1856: 108-109). Среди новых научных методов указывалось на необходимость исследования мочи (Там же: 103). Изложив 
характерные особенности развития плода по месяцам, А.П. Матвеев впервые в русской науке хронометрировал беременность (от 280 до 308 дней). При этом «болезненным состояниям» беременных он посвятил отдельный том «Курса акушерства...»- лучшее доказательство значимости описаний патологий для утверждении профессионализма врача (Матвеев 1857).

К середине XIX в. в России расширились рамки оперативного акушерства в клинических условиях, еще более упрочив значимость экспертного знания и его преимущества перед практическим опытом тех же повитух. В третьем томе своего труда А.П. Матвеев рассмотрел дюжину видов акушерских операций, среди которых: искусственное «прободение оболочек яйца», наложение акушерских щипцов, поворот на ножку, поворот на головку, поворот на зад, извлечение руками, прободение головки младенца, эмбриотомия, «кесарское сечение», гастротомия, «насильственное произведение родов» (аборт), искусственное отделение детского места, искусственный выкидыш. Он первым обосновал тем самым возможность аборта с сохранением жизни матери, операции при внематочных и многоплодных беременностях.

В акушерской науке началось стремительное введение технических новшеств. Врачи экспериментировали, стремясь облегчить течение родового процесса, одновременно увеличивая собственную значимость и уважение к своему профессионализму в глазах «пациенток». Едва Н. И. Пирогов запатентовал в 1847 г. возможность применения наркоза (хлороформа) в хирургии, как врачи-акушеры стали экспериментировать с ним в трудных родах. Постоянно рационализируя родовой процесс, стремясь доказать превосходство научных знаний над народным опытом, врачи подчеркивали, что направляют усилия на сострадательную помощь, обезболивание и облегчение акта производства детей на свет.

Акушерство и хирургия сблизились настолько, что возник термин «хирургическое акушерство». Акушеры получили абсолютное превосходство над повитухами в области операции «кесарского сечения» (Китер 1857), в ходе которой женщина стала описываться объектно: она уже не рожала, это врачи «извлекали плод» из ее чрева. Как и предшественники, русские врачи середины XIX в. не предполагали необходимости зашить разрезанную матку» (Матвеев 1858: 192), что продолжало вести к высокой смертности рожениц.

С середины 1850-х гг. в российской медицинской литературе было подчеркнуто, что акушерство и гинекология - это разделы хирургии, поэтому методы исследования и лечения должны быть хирургическими. Именно в этом направлении стала прогрессировать научная мысль, изучающая «жизнь женщины, в отношении половых отправлений» (Кораблев 1843:5). А.А. Китер был первым в России, кто решился на проведение операции по хирургическому удалению матки - гистерэктомию (Груздев 1910: 42-44), ввел в практику использование маточного зеркала, прижигание шейки матки азотнокислым серебром (ляписом). 
Особое внимание к акушерским манипуляциям во время трудных родов, использование специальных акушерских инструментов стали вызывать всё больший интерес в работах отечественных врачей. И. П. Лазаревич предметом своих научных исследований сделал анализ последствий впрыскивания в матку различных смесей для стимулирования родового процесса (Лазаревич 1858). Женское тело (в клиническом пространстве) было для него объектом многочисленных экспериментов, результаты которых он старался незамедлительно публиковать. Он лично разрабатывал подручные инструменты для использования при акушерских операциях, ввел во врачебную практику акушерский анамнез пациенток: начало регул, общее состояние здоровья, перенесенные заболевания, характер протекания предыдущих беременностей, родов и т.д. (Там же:45-47). Открытым и спорным для врачей того времени оставался вопрос о послеродовом бандаже и перевязывании живота после родов для лучшего сокращения матки и восстановления женского организма. Сторонники перевязок и бандажа по сути реабилитировали эту практику народного акушерства (Матвеев 1856:316). Менее обоснованными современным врачам представляются популярные и рекомендованные тогда особые послеродовые диеты, усиленный прием успокоительных, в том числе опиума и морфия, кровопускание, гирудотерапия (наказ «приставлять пиявок на живот»).

\section{Заключение}

C конца XVIII в. в России началось проникновение врачей-акушеров в сферу родовспоможения; оно не было столь агрессивным, как в истории западноевропейского акушерства. Гендерные стереотипы общества, устойчивость «женского пространства» родов выступали мощными препятствиями на пути медикализации родовспоможения. Повитухи продолжали быть основными участницами родов, именно повитух призывали на роды как в семьи привилегированных слоев населения, так и в семьи простолюдинов. Прослеживался значительный разрыв между теорией акушерской науки и практикой. Научному акушерству не удавалось вытеснить народное акушерство, женское пространство родов продолжало доминировать. Врачам было сложно проникнуть в «родильную комнату», в связи с устойчивым представлением общества о недопустимости присутствия посторонних мужчин при столь интимной процедуре, как роды.

Сфера родовспоможения стала включаться в социальный контроль со стороны государства, вовлекаться в сферу медицинского контроля по пути обоснования престижа и профессионализма врачей-акушеров (неовеберианская перспектива). В этой связи авторитет научного акушерства утверждался за счет развития учения об оперативном (хирургическом) акушерстве. Акушерские операции, применение новых технологических инструментов, гинекологические операции, особое «акушерское исследование» при помощи 
инструментов становились явными преимуществами врача. Научное акушерство утверждалось со стороны патологии и утверждения престижа врача перед лицом повитухи. Клиническое пространство стало сферой для деятельности врача-акушера, в то время как домашнее пространство для повитух. Результатом развития акушерских знаний и медицинских амбиций мужчин-врачей стало то, что в научном акушерстве женское тело превращалось в объект наблюдений, контроля и особых практик со стороны медиков. Роженица из активного участника, субъекта родовой деятельности, по крайней мере в теории медицинских учебников, становилась пассивным объектом врачебных манипуляций. Именно медицина была институтом, нормализирующим или патологизирующим материнство, а медицинские критерии - ключевыми для разделения материнства на «нормальное» и «ненормальное».

Процесс медикализации женского репродуктивного здоровья шел быстро. Повивальное искусство сконцентрировалось исключительно на процессе родоразрешения, акушерская же наука, включив в себя учение о половом развитии женского организма, взяла под контроль целый жизненный период женщины - от созревания до беременности, родов, послеродового восстановления (включая период грудного вскармливания) и женских болезней. К середине XIX в. утверждалась иерархия в деятельности врача-акушера и повитухи. Врачи-акушеры стали контролировать область патологического акушерства, оказывая пособие при «трудных родах». Носителем «экспертного знания» постепенно становились не акушерки, а врачи-мужчины, которые всё активнее стали отстаивать свой авторитет в профессии. Акушерки заняли подчиненное положение по отношению к врачам. Формировалась усредненная модель «правильных» и «неправильных родов», любые отклонения от «нормы» стали рассматриваться как повод для врачебного вмешательства.

\section{Выражения признательности}

Исследование подготовлено при финансовой поддержке Росийского фонда фундаментальных исследований: проект № 16-01-00136 «Репродуктивное поведение, родильные и акушерские практики в России XVI-XXI вв.: медико-антропологический и историко-этнологический анализ», проект № 17-31-01020 «Взаимодействие государства и провинциального общества в формировании национальной модели медико-социальной работы России в XIX - начале XX в.»

\section{Список источников}

Бодлок Ж. Л. (1786) Городская и деревенская повивальная бабка, М.: Университетская типография.

Верман К. (1832) Руководство к обучению повивальному искусству, М.: Типография Лазаревых. 
Горн И. Ф. (1834) Теоретическое и практическое акушерство. Ч. 1-2, СПб.: Типография К. Вингебера.

Груздев В.С. (1910) Краткий очерк истории акушерства и гинекологии в России. Акушерскогинекологические учреждения России, СПб.: Государственная типография: 5-76.

Данилишина Е.И. (1998) Основные этапы и направления развития отечественного акушерства (XVIII-XX вв.). Автореф. дис. д.м.н. М.

Дейч К.Ф. (1841) Лучшее приданое или необходимые наставления для беременных, рожении и родильнии, М.: Типография Н. Степанова.

Здравомыслова Е.А., Темкина А.А. (2015) 12 лекций по гендерной соииологии, СПб.: Издательство Европейского университета в Санкт-Петербурге.

Карус К.Г. (1836) Учебная книга гинекологии, СПб.: Типография Штаба Отделения корпуса внутренней стражи.

Китер А.А. (1857) Руководство к изучению акушерской науки. Ч. 1, СПб.: Типография Я. Трея. Константинович И. (1802) Краткое начертание повивальнаго искуства, СПб.: Типография Государственной медицинской коллегии.

Кораблев Г.И. (1841-1843) Курс акушерской науки и женских болезней, М.: Типография И. Смирнова.

Лазаревич И.П. (1858) Впрыскивание в матку как средство, вызывающее мымечную деятельность этого органа, с иелью искусственного возбуждения преждевременных родов, Киев: Университетская типография.

Левитский Д. И. (1821) Руководство к повивальной науке, М.: Типография А. Семена.

Максимович-Амбодик Н.М. (1784-1786) Искусство повивания или Наука о бабичьем деле. Ч. 1-4, СПб.: Императорская типография.

Матвеев А.П. (1856-1858) Курс акушерства для учащихся. Т. 1-3, Киев: Университетская типография.

Никитин А.Н. (1847) Диэтетика беременных, родильниц и детей, СПб.: Типография Э. Праца. Пушкарева Н.Л. (1996) Женщины России и Европь накануне Нового времени, М.: Ломоносов. Романов П., Ярская-Смирнова Е. (2013) Власть знания и общественные интересы: профессионалы в государстве благосостояния. П. Романов, Е. Ярская-Смирнова (ред.) Профессии сочиального государства, М.: Вариант: 7-21.

Темкина А.А. (2014) Медикализация репродукции и родов: борьба за контроль. Журнал исследования сочиальной политики, 3 (12):321-336.

Фуко М. (2010) Рождение клиники, М.: Академический проект.

Холостова Е.И. (2013) Социальная политика, М.: Юрайт.

Цвелев Ю.В. (2006) Заслуженный профессор Московского университета акушер В.М. Рихтер. Журнал акушерства и женских болезней, (3): 85-87.

Яковенко Т. Г. (2008) Охрана материнства и младенчества во второй половине XVIIIнач. ХХ в.: на материалах Санкт-Петербурга. Дис... к. и.н. СПб.

Abbott A. (1988) The System of Professions: An Essay on the Division of Expert Labour, Chicago: University of Chicago Press.

Borst C. G. (1995) Catching Babies: The Professionalization of Childbirth, 1870-1920, Cambridge, MA: Harvard University Press.

Gelis J. (1991) History of Childbirth: Fertility, Pregnancy and Birth in Early Modern Europe, Boston: Northeastern University Press.

Green M. H. (2008) Making Women's Medicine Masculine: The Rise of Male Authority in PreModern Gynecology, Oxford: Oxford University Press.

Leavitt J. W. (1986) Brought to Bed. Childbearing in America 1750-1950, Oxford: Oxford University Press.

Wilson A. (2013) Ritual and Conflict: The Social Relations of Childbirth in Early Modern England, Farnham: Ashgate. 
Natalya Pushkareva, Natalia Mitsyuk

\section{THE ORIGINS OF MEDICALIZATION: THE BASIS OF RUSSIAN SOCIAL POLICY IN THE FIELD OF REPRODUCTIVE HEALTH (1760-1860)}

This article examines the processes behind the transition from traditional to scientific obstetrics in Russia during Late Modern period. Our aim in doing this is to analyse the processes of medicalization and pathologization of birth within medical discourse. To do this we examine Russian obstetric literature since the 1760 s to the middle of the nineteenth century. The emergence of scientific obstetrics in Russia in the second half of the eighteenth century was partly due to the development of scientific medicine and the opening of the first educational institutions for 'povituchi'. One barrier to the dissemination of scientific obstetrics came in the form of gender stereotypes claiming it was unacceptable for men to examine the female body. Doctors, seeking to prove their own authority and superiority over traditional obstetrics, wrote about the special political importance of this business. The authority of the science of obstetrics was established through the development of the doctrine of operative obstetrics. Obstetric operations, the use of new technological instruments and gynecological operations became advantages of clinical physicians. Doctors asserted their social control over the sphere of procreation through the pathologization of birth. Clinical space was transformed into the area of experimentation on the female body, which came to be regarded as an object of observation. Women went from being active participants, subjects of labour to becoming passive objects of medical manipulations. The process of medicalization with regards female reproductive health also included obstetric science claiming control over the whole life of the woman: from puberty to pregnancy, childbirth and postnatal restoration. The average 'correct' model was formed as well as 'the wrong childbirth'. Any deviations from these 'norms' became viewed as cause for medical intervention.

Key words: the history of childbirth, history of midwifery, the medicalization, midwives.

DOI: $10.17323 / 727-0634-2017-15-4-515-530$

\section{References}

Abbott A. (1988) The System of Professions: An Essay on the Division of Expert Labour, Chicago: University of Chicago Press.

Natalya L. Pushkareva - Grand PhD (History), Professor of the Institute of Ethnology and Anthropology RAS, Moscow, Russian Federation. Email: pushkarev@mail.ru

Natalia A. Mitsyuk - Grand PhD (History), Associate Professor, of the Smolensk State Medical University, Russian Federation. Email: mitsyuk.natalia@gmail.com 
Bodlok Z. (1786) Gorodskaja i derevenskaja povival'naja babka [Urban and Rural Midwife], Moscow: Gorodskaja tipografija.

Borst C. (1995) Catching Babies: The Professionalization of Childbirth, 1870-1920, MA: Harvard University Press.

Cvelev Ju.V. (2006) Zasluzhennyj professor Moskovskogo universiteta akusher V. M. Rihter [Honored Professor of Moscow University and the Obstetrician V. M. Richter]. Zhurnal akusherstva i zhenskih boleznej [Journal of Obstetrics and Women's Diseases], 3: 85-87.

Danilishina E. I. (1998) Osnovnye jetapy i napravlenija razvitija otechestvennogo akusherstva $(X V I I I-X X)$ [Main Stages and Directions of Development of Domestic Obstetrics (XVIII-\$5X)]. PhD Dissertation. Moscow.

Dejch K. F. (1841) Luchshee pridanoe ili neobhodimye nastavlenija dlja beremennyh, rozhenic i rodil'nic [The Best Dowry or Necessary Guidance for Pregnant Women, Childbirth and Postpartum], Moscow: Tipografija N. Stepanova.

Foucault M. (2010) Rozhdenie kliniki [The Birth of the Clinic], Moscow: Akademicheskij proekt.

Gelis J. (1991) History of Childbirth: Fertility, Pregnancy and Birth in Early Modern Europe, Boston: Northeastern University Press.

Gorn I.F. (1834) Teoreticheskoe i prakticheskoe akusherstvo [Theoretical and Practical Obstetrics]. Ch. 1-2. St. Petersburg: Tipografija K. Vingebera.

Green M.H. (2008) Making Women's Medicine Masculine: The Rise of Male Authority in Pre-Modern Gynecology, Oxford: Oxford University Press.

Gruzdev V. S. (1910) Kratkij ocherk istorii akusherstva i ginekologii v Rossii [A Short History of Obstetrics and Gynecology in Russia]. Akushersko-ginekologicheskie uchrezhdenija Rossii [Obstetric-Gynecologic Institutions of Russia], St. Petersburg: Gosudarstvennaja tipografija: 5-76.

Holostova E. I. (2013) Social’naja politika [Social Policy], Moscow: Jurajt.

Jakovenko T.G. (2008) Ohrana materinstva i mladenchestva vo vtoroj polovine XVIII nach. XX v.: na materialah Sankt-Peterburga [The Protection of Motherhood and Infancy in the Second Half of XVIII - Early XX Century: on Materials of St. Petersburg]. PhD Dissertation. St. Petersburg.

Karus K. G. (1836) Uchebnaja kniga ginekologii [Textbook of Gynecology], St. Petersburg: Tipografija Shtaba Otdeleniaj korpusa vnutrennej Strazhi.

Kiter A.A. (1857) Rukovodstvo k izucheniju akusherskoj nauki [Guide to the Study of Obstetric Science]. Vol. 1., St. Petersburg: Tipografija Ja. Treja.

Konstantinovich I. (1802) Kratkoe nachertanie povival'nago iskusstva [A Brief Outline of the Midwifery Arts], St. Petersburg: Gosudarstvennaja tipografija.

Korablev G. I. (1841-1843) Kurs akusherskoj nauki i zhenskih boleznej [Course of Obstetric Science and Women's Diseases], Moscow: Tipografija I. Smirnova.

Lazarevich I.P. (1858) Vpryskivanie v matku kak sredstvo, vyzyvajushhee myshechnuju dejatel'nost' jetogo organa, s cel' ju iskusstvennogo vozbuzhdenija prezhdevremennyh rodov [Injection into the Uterus as a Means of Causing Muscle Activities of that Body, with the Aim of Excitation of Preterm Birth], Kiev: Universitetskaja tipografija. 
Leavitt J. W. (1986) Brought to Bed. Childbearing in America 1750-1950, Oxford: Oxford University Press.

Levitskij D. I. (1821) Rukovodstvo k povival'noj nauke [A Guide to Midwifery Science], Moscow: Tipografija A. Semena.

Maksimovich-Ambodik N.M. (1784-1786) Iskusstvo povivanija ili Nauka o babich'em dele [Birth Science or the Science about Babich's Case]. Vol. 1-4, St. Petersburg: Imperatorskaja tipografija.

Matveev A.P. (1856-1858) Kurs akusherstva dlja uchashhihsja [Obstetrics Course for Students], Vol. 1-3. Kiev: Universitetskaja tipografija.

Nikitin A. N. (1847) Dijetetika beremennyh, rodil'nic i detej [Dieting in Pregnant Women, Postpartum Women and Children], St. Petersburg: Tipografija E. Praca.

Pushkareva N.L. (1996) Zhenshhiny Rossii i Evropy nakanune Novogo vremeni [The Women of Russia and Europe to Modern Times], Moscow: Lomonosov.

Romanov P., Iarskaia-Smirnova E. (2013) Vlast' znanija i obshhestvennye interesy: professionaly v gosudarstve blagosostojanija [The Power of Knowledge and Public Interest: Professional and State Welfare]. P. Romanov, E. Iarskaia-Smirnova (eds.) Professii social'nogo gosudarstva [Professions of the Welfare State], Moscow: Variant: 7-21.

Temkina A. A. (2014) Medikalizacija reprodukcii i rodov: bor'ba za kontrol' [The Medicalization of Reproduction and Childbirth: The Struggle for Control]. Zhurnal issledovanii social'noj politiki [The Journal of Social Policy Studies], 3 (12):321-336.

Verman K. (1832) Rukovodstvo k obucheniju povival'nomu iskusstvu [A Guide to Learning the Art of Midwifery], Moscow: Tipografija Lazarevyh.

Wilson A. (2013) Ritual and Conflict: The Social Relations of Childbirth in Early Modern England, Ashgate Publishing Ltd.

Zdravomyslova E.A., Temkina A.A. (2015) 12 lekcij po gendernoj sociologii [12 Lectures on Gender Sociology.], St. Petersburg: Izdatel'stvo Evropejskogo universiteta v Sankt-Peterburge. 